Agnieszka Paterska-Kubacka

Instytut Orientalistyki, Uniwersytet im. Adama Mickiewicza w Poznaniu

\title{
Polska literatura dziecięca w Chinach
}

Polska literatura piękna jest obecna w Chinach od 1906 roku. Pierwszym utworem reprezentującym polską prozę, który został przełożony na język chiński, był Latarnik (Dengtaishou) Henryka Sienkiewicza. Podstawą tych wczesnych przekładów nie były polskie oryginały. W tym wypadku tłumacz, Wu Chou, wykorzystał wersję japońską, którą przetransformował na klasyczny język chiński. Jak pisze Li Yinan:

Polska literatura piękna dotarła do Chin z pewnym opóźnieniem. Możemy wszak cieszyć się z tego, że współcześni chińscy literaci włożyli wiele wysiłku w rozpowszechnienie literatury polskiej, dzięki czemu w ciągu niespełna 100 lat dorobek przekładowy arcydzieł literatury polskiej w Chinach znacznie się powiększył. [Li 2017: 28-29]

Ogromny wkład w owo „rozpowszechnianie literatury polskiej” miał Lu Xun (właśc. Zhou Zuoren, 1881-1936), jeden z najwybitniejszych pisarzy chińskich Xx wieku zwany „ojcem prozy chińskiej”. Z tabeli, którą w swoim opracowaniu zamieściła Li Yinan [2017: 29-30], wynika, że Lu Xun był tłumaczem 25 Z 40 wydanych w latach 1906-1948 nowel i powieści polskich. Zde- 
cydowanie najczęściej tłumaczonym autorem był Sienkiewicz (1846-1916) - przełożono w tamtym czasie kilkanaście jego utworów, m.in. Sachema, Janko Muzykanta, Latarnika czy Quo vadis, niektóre wielokrotnie. W 1920 roku opublikowano trzy tłumaczenia prozy Stefana Żeromskiego (1864-1925), w 1921 roku - tłumaczenia dzieł Marii Konopnickiej (1842-1910), przekładano także utwory m.in. Adama Mickiewicza (1798-1855), Władysława Reymonta (1867-1925) i Bolesława Prusa (1847-1912).

Latarnik to prawdopodobnie najwcześniej przetłumaczony na język chiński utwór literatury wschodnioeuropejskiej, który zapoczątkował historię tych tłumaczeń we współczesnych Chinach. Zainteresowanych historią przekładów polskiej literatury na chiński oraz recepcją tejże w Chinach odsyłam do publikacji prof. Yi Lijun i dr Li Yinan, które opracowały ten temat bardzo szczegółowo.

Żadna z analiz dotyczących polskiej literatury pięknej, z którymi miałam dotąd do czynienia, nie wspomina o tłumaczeniach polskiej ani też wschodnioeuropejskiej literatury dziecięcej. Napisałam wyżej, że jedną z pierwszych rodzimych autorek tłumaczoną na język chiński była Konopnicka. W jej dorobku znajdują się także teksty skierowane do dzieci, ale dwa utwory, które w 1921 roku przełożył Zhou Zuoren: A jak poszedł król na wojnę i Moja cioteczka, trudno zaliczyć do kanonu literatury dziecięcej. Po kilku miesiącach spędzonych na poszukiwaniu materiałów naukowych (a najbardziej zależało mi na źródłach chińskojęzycznych), próbach nawiązania kontaktu z chińskimi i polskimi wydawnictwami, a nawet nachalnym zaczepianiu przez Messenger autorów i ilustratorów doszłam do wniosku, że postawiłam przed sobą zadanie przekraczające moje możliwości, a napisanie artykułu o polskiej literaturze dziecięcej w Chinach zakrawa na szaleństwo. Jednak, trochę jak w bajce, znalazłam na swej drodze kilku magicznych pomocników, którym jestem niezmiernie wdzięczna. To oni podsunęli mi pewne tropy i dzięki nim podejmuję to wyzwanie.

\section{Propaganda sukcesu}

Skąd wziął się pomysł pisania o polskiej literaturze dziecięcej w Chinach? Z tkwiącego w mojej podświadomości niezachwianego przeko- 
nania, że ma się tam ona świetnie, a pozytywne informacje dotyczące wszelkich „produktów made in Poland” należy rozpowszechniać „ku pokrzepieniu serc”. Skąd przekonanie, że Chińczycy na pniu wykupują tłumaczone z języka polskiego książki dla dzieci? W dużej mierze z krążących w świecie sinologicznym plotek, które słyszałam, oraz $\mathrm{z}$ artykułów publikowanych w Internecie. Jednak, jak już wspomniałam, odnalezienie źródeł nie było tak łatwe, jak sądziłam. Zaczęłam od najbliższego mi kręgu sinologów poznańskich i okazało się, że nikt nie podziela mojej wiary w wielki sukces polskiej literatury dziecięcej wśród chińskich czytelników. Nie wynikało to z wrodzonego nam, Polakom, pesymizmu, ale właśnie $\mathrm{z}$ braku informacji... Nieco podniosły mnie na duchu tytuły kilku artykułów, które odnalazłam w sieci. Na portalu Kresy.pl w tekście Milion książek polskich autorów sprzedanych w Chinach [Kaźmierczak 2017] można przeczytać, iż „Aleksandra i Daniel Mizielińscy sprzedali w Chinach książki w nakładzie ponad miliona egzemplarzy” i odnieśli „największy sukces wydawniczy na niełatwym chińskim rynku”. Tę samą wiadomość znajdziemy w notatce Polacy sprzedali ponad milion książek w Chinach [Sajewicz 2017], ale są to nieliczne i krótkie newsy. Entuzjastyczne informacje o obecności tego rodzaju literatury na chińskim rynku wydawniczym pojawiły się w 2016 roku na portalu Culture.pl: „Polska wspólnie z 15 krajami regionu była gościem honorowym największych azjatyckich targów książki Beijing International Book Fair, które odbywały się od 23 do 28 sierpnia 2016 roku w Pekinie”; „Po raz pierwszy na pekińskich targach polska literatura i rynek książki zostały pokazane w równie obszerny sposób. Na 200-metrowym stoisku [... ]”; „Polskie książki dla dzieci z roku na rok stają się w Chinach coraz popularniejsze” [Polskie książki w chinach 2016].

Od wielu lat w Beijing International Book Fair uczestniczy Instytut Książki. Jego przedstawiciele prezentują „książki polskich autorów”, namawiając „chińskich wydawców do zainte[re] sowania się naszymi tytułami” oraz informując „o możliwościach uzyskania wsparcia, jeśli zdecydują się na wydanie przekładów w Chinach”. Jak podano na stronie internetowej Instytutu Książki: „Pokazujemy głównie polskie książki dla dzieci oraz tytuły dofinansowane ostatnio przez Program Translatorski CPoland" [Polska na targach... 2012]. 
Skoro więc jednak miałam rację, skoro polskie książki dla dzieci „stają się coraz popularniejsze” w Chinach i wkrótce zaczną powstawać prace dyplomowe na ich temat, pozwolę sobie zacząć tę serię publikacji niniejszym artykułem.

\section{Kto thumaczy?}

Moją pracę rozpocznę od przedstawienia Pekińskiego Uniwersytetu Języków Obcych (Beijing Waiguoyu Daxue; skrót: PUjo) i pani prof. Yi Lijun, „Ambasadora Polszczyzny”, o której jeden z jej uczniów, Zhao Gang, napisał: „Coraz rzadziej zdarza się, żeby jedna osoba kształtowała oblicze jakiegoś kierunku badań naukowych w danym kraju. Pani prof. Yi Lijun jest właśnie taką osobą" [Zhao 2010: 25]. Od wielu lat pracuje na PUJo, gdzie otwarto pierwszą w Chinach i do niedawna jedyną polonistykę, a

W ciągu blisko 50 lat Yi Lijun wraz z innymi wykładowcami i lektorami wykształciła blisko 200 absolwentów polonistyki. Niektórzy z nich pełnią już ważne funkcje w instytucjach państwowych, placówkach dyplomatycznych czy w biznesie. [Zhao 2010: 30]

W 2007 roku Uniwersytet Gdański nadał prof. Yi tytuł doktora honoris causa

za oryginalność sposobu prezentacji literatury polskiej w Chinach poprzez heroiczną pracę translatorską, wychowanie wielu pokoleń chińskich polonistów i wzorcową działalność organizacyjną w zakresie współpracy naukowej z polskimi ośrodkami akademickimi. [Doktorzy Honorowi Uniwersytetu Gdańskiego 2020]

Jej nazwisko nie pojawia się na stronie tytułowej żadnej z polskich książek dla dzieci, które wydano w Chinach w ostatnich latach,

1 Tytuł przyznany w 2008 roku przez Radę Języka Polskiego przy prezydium Polskiej Akademii Nauk za wieloletnie krzewienie języka polskiego i literatury polskiej w Chinach [Zhao 2010: 30]. 
ale z ogromnym prawdopodobieństwem można powiedzieć, że bez jej obecności w chińskim świecie nauki wiele z tych pozycji nie ukazałoby się wcale. A już na pewno literatura polska nie zyskałaby tak wielu wspaniałych tłumaczy, absolwentów PUjo, będących jednocześnie wielkimi miłośnikami i kolejnymi krzewicielami polskiej kultury. Należą do nich m.in.:

- Wu Lan - profesor, obecnie zatrudniona na Uniwersytecie Gdańskim, w której dorobku znajdują się takie pozycje, jak: Podróże z Herodotem, Cesarz i Imperium Ryszarda Kapuścińskiego, Zniewolony umyst Czesława Miłosza, Ksiega listów Brunona Schulza czy poezja Zbigniewa Herberta i Adama Zagajewskiego [Instytut Polski Wydział Kultury... 2016].

- Zhao Gang - profesor, obecnie dziekan Wydziału Języków i Kultur Europy na PUjo i dyrektor Centrum Studiów Polskich Pekińskiego Uniwersytetu Studiów Zagranicznych (BFSU); wielokrotnie uhonorowany za działalność „na rzecz relacji polsko-chińskich”; tłumaczył m.in. teksty Stanisława Lema, Zbigniewa Herberta, Czesława Miłosza [Instytut Polski Wydział Kultury... 2016].

- Qu Pengjie - pracuje jako dziennikarz w polskiej sekcji Chińskiego Radia Międzynarodowego (China Radio International, Zhongguo Guoji Guangbo Diantai), jest tłumaczem, a ponadto „uczestniczył w produkcji tłumaczenia chińskiej wersji polskiego serialu «Przepis na życie», którego 39 odcinków wyemitowała kilka lat temu Centralna Telewizja Chińska (сстv)” [Instytut Polski Wydział Kultury... 2016].

- Zhong Lei - wykładowca wizytujący Uniwersytetu Warszawskiego, także zatrudniony w Chińskim Radiu Międzynarodowym, autor słowników i podręczników do nauki języka chińskiego dla Polaków [Instytut Polski Wydziat Kultury... 2016].

- Li Jia - absolwentka polonistyki na PUjo; amatorsko tłumaczy polską literaturę, pracuje w Gdańsku, w Chińsko-Polskim Towarzystwie Okrętowym [Instytut Polski Wydziat Kultury... 2016].

Polonistyka na PUjo przez ponad pół wieku była jedyną w całych Chinach. Powstała w 1954 roku na Wydziale Rusycystyki 
Uniwersytetu Pekińskiego (Beijiing Daxue) [Prokop 2016: 27]. W ostatnich latach można jednak zaobserwować spory wzrost zainteresowania naszym krajem i nauką języka polskiego wśród Chińczyków, ponieważ tego typu specjalności przybywa. W 2008 lub 2009 roku² otwarto polonistykę na Uniwersytecie Pedagogicznym w Harbinie (Ha'erbin Shifan Daxue), w 2013 roku utworzono lektorat języka polskiego na Wydziale Języków Obcych (Waiguoyu Xueyuan) na Uniwersytecie Północno-Wschodnim (Dongbei Daxue) w Shenyang (Shenyang Shi) oraz na Uniwersytecie w Zhaoqing (Zhaoqing Xueyuan, prow. Guangdong [Guangdong Sheng]), w 2014 roku powstał Instytutu Polonistyki na Kantońskim Uniwersytecie Spraw Międzynarodowych (Guangdong Waiyu Waimao Daxue) [Prokop 2016: 35-37, 39, 42], a w 2017 roku studia o takiej specjalności otworzył Szanghajski Uniwersytet Studiów Międzynarodowych (Shanghai Waiguoyu Daxue) [Poloniści z Szanghaju... 2017]. Daria Prokop [2016: 30] podaje, że zainteresowanie polonistyką na PUJo bywa naprawdę duże: „[... ] na jedno miejsce zgłasza się ponad dwadzieścia osób”.

Wobec takiego rozkwitu polonistyki w Chinach można się spodziewać, że tłumaczy i tłumaczonych dzieł, w tym także literatury dziecięcej, będzie coraz więcej.

\section{Kogo tłumaczą?}

Jeśli kogoś zastanawiałoby, jak to się dzieje, że konkretne polskie tytuły trafiają do chińskich wydawców, i dlaczego wybierane są właśnie te, a nie inne pozycje, odpowiedzi powinien poszukać na stronie internetowej Instytutu Książki. Jeśli chodzi o literaturę dziecięcą, to ich wyboru dokonuje się

ze szczególnym uwzględnieniem pozycji nagrodzonych w konkursach „Książka Roku” organizowanych przez polską sekcję IBBY oraz tych wydanych przez Naszą Księgarnię i Dwie Siostry - domy wydawnicze, których książki jak dotąd cieszą się

2 Szczegółowe informacje można znaleźć w pracy magisterskiej Darii Prokop [2016: 35-36]. 
największym zainteresowaniem chińskich wydawców. [Beijing International Book... 2015]

Dwa lata temu Instytut Książki donosil, iż „polskie książki dla dzieci” zaskarbiły sobie w Chinach tak „olbrzymią popularność”, że „w ostatnich latach do Chin sprzedano licencje do blisko 90 tytułów”. Wśród firm wydawniczych, których publikacje najchętniej tłumaczą i drukują Chińczycy, znowu wymienia się Dwie Siostry oraz Naszą Księgarnię, ale także wydawnictwa Media Rodzina i Wytwórnia [Kaluta 2018].

Wśród tłumaczonych polskich autorów prym wiodą natomiast Aleksandra i Daniel Mizielińscy. Ich prace - bo chyba to słowo jest bardziej adekwatne w stosunku do ich książek niż teksty - są bardzo popularne wśród małych czytelników w Polsce (co piszę również na podstawie własnych doświadczeń). $Z$ wykształcenia graficy, jako twórcy literatury dziecięcej wyrobili sobie własną, rozpoznawalną markę, a pozycja pt. Mapy. Obrazkowa podróż po lądach, morzach $i$ kulturach świata, opublikowana w 2012 roku przez Dwie Siostry, została wydana już w 35 krajach [Nuoya 2015]. Izabella Kaluta [2018] pisze wprost, że jeśli chodzi o polskie książki non-fiction dla dzieci, to „Za gwiazdy tego gatunku w Chinach uważani są Aleksandra i Daniel Mizielińscy, których Mapy czy Pod ziemia, pod woda wyznaczyły nowe trendy i przetarly szlaki innym polskim ilustratorom i autorom". W latach 2014-2020, oprócz wspomnianych już Map (2014 i 2018, Ditu (renwen ban), przel. Feng Ting) i Pod ziemia, pod woda (2015, Dixia, shuixia, przeł. Wu Lan), w Chinach wydano także następujące tytuly tych twórców:

- Mamoko3 (2016, Mama kan! Xiandai shijie, przeł. Hui Xuan).

- Mamoko (2016, Mama kan! Long de shidai, przel. Hui Xuan).

- Mamoko (2016, Mama kan! Gongyuan 3000 nian, przel. Hui Xuan).

- Kosmos (2016, Taikong, przeł. Wu Lan, Liu Boyang).

- Kto kogo zjada (2017, Shei chi shei, przet. Wu Lan).

- Ale patent! (2017, Bukesiyi de faming!, przel. Wu Lan, Li Jia).

3 Oryginalne polskie tytuły brzmią: Miasteczko Mamoko, Dawno temu w Mamoko, Mamoko 3000. 
- Jeden dzień (2020, Wo de yi tian, przeł. Bolan Shiguan Wenhuachu / Cultural Service of the Embassy of Poland in Beijing) [Hao 2020; Jaśkowski 2020].

- D.O.M.E.K. (dwukrotnie, w dwóch różnych wydawnictwach, przeł. Lv Lu; Ji Jiann-mei ${ }^{4}$ ).

- D.E.S.I.G.N. (z Ewą Solarz, dwukrotnie, w dwóch różnych wydawnictwach, przeł. Jiang Yuije; Ji Jiann-mei).

- S.Z.T.U.K.A. (przeł. Zhang Yun) [Adamski 2020].

W chińskojęzycznych recenzjach i opisach książek Mizielińskich - a dostępne materiały dotyczą głównie Map, Pod ziemia, pod wodą oraz Mamoko! - pojawiają się takie frazy, jak: „fascynująco szczegółowa”, „wyjątkowo delikatne barwy”, „żartobliwy styl”, czy wreszcie „każda strona to zaproszenie w podróż dookoła świata, to książka obrazkowa, która stanowi narzędzie rozwijające dziecięce zainteresowania i chęć eksplorowania Ziemi i świata” oraz „to boskie dzieło, które bez wątpienia także dorosłym pozwoli gruntownie uzupełnić wiedzę oraz sprawi, że będą przed nim padać na kolana" [Du le jiu... 2018 $]^{5}$.

W promocję zaangażowano takie autorytety, jak prof. Chen Jia’er, biolog, rektor Uniwersytetu Pekińskiego, członek Chińskiej Akademii Nauk (Zhongkeyuan), który uważa, że

Pod ziemia, pod woda to bardzo ciekawa pozycja, która pozwala dzieciom zdobyć dużo wiedzy na temat struktury dna oceanu, struktury Ziemi, organizmów żyjących na dnie oceanu, nowoczesnej ekologii. Sądzi on, że powinno być więcej pisarzy, którzy poświęcaliby się popularyzacji nauki wśród dzieci, ponieważ «przeciętny pracownik naukowy jest bardzo zajęty, ma swoje obowiązki, takie jak publikowanie artykułów, tymczasem pracownik naukowo-techniczny nie powinien na tym poprzestawać, ale powinien także rozpowszechniać wiedzę,

5 Wszystkie cytaty przytoczone w tekście zostały przetłumaczone przez autorkę A.P.K. 
którą opanowal, by zrozumiało ją cała społeczeństwo. Młode pokolenie ma taki potencjał i może to robić. [Nuoya 2015]

Jak rozumiem, przedstawicielami tego młodego pokolenia są właśnie Mizielińscy, którzy realizują taką misję. Z kolei dyrektor Biura ds. Kulturalnych przy Ambasadzie Rzeczypospolitej Polskiej w Chinach Magdalena Czechońska nazwała książkę „nowym emisariuszem wymiany kulturalnej pomiędzy Chinami a Polską" [Nuoya 2015]. W artykułach powtarza się też stwierdzenie, że jest to pozycja, która pomaga rodzicom przekonać dzieci do czytania, którą sami chętnie czytają wspólnie ze swoimi pociechami i z której sami czerpią wiedzę [Nuoya 2015; Du le jiu... 2018; Guo 2020].

W 2016 roku w jednym pakiecie ukazało się sześć książek Wojciecha Widłaka z serii Pan Kuleczka (Xiaoqiu Xiansheng): Pan Kuleczka (Jingxi [niespodzianka ${ }^{6}$ ]), Skrzydta (Feixiang [latać]), Spotkanie (Dahai [morze]), Światto (Guangmang), Dom (Xiaochuan [łódź]), Radość (Yiqie [wszystko]). Jak napisał sam autor:

Pan Kuleczka znalazł się w Chinach dzięki pani Izabelli Kalucie [...], która pracowała w Instytucie Książki [...], oraz dzięki Peijian Xing, właścicielce wydawnictwa Red Hat Books, i profesorowi Zhao Gang, który mimo nawału pracy naukowej zechciał sześć tomików przetłumaczyć. [Widłak 2020a]

Według twórcy „Pan Kuleczka, niestety, raczej nie odniósł wielkiego sukcesu komercyjnego" [Widłak 202ob], ale otrzymał pozytywne recenzje. Niestety, nie udało mi się odnaleźć wielu informacji na temat tej serii, wśród materiałów dostępnych w Internecie króluje powtarzany i cytowany na rozmaitych stronach artykuł opublikowany przez „The Beijing News” [Kong, Zhao 2017], którego częścią jest wywiad z pisarzem. Podano w nim informacje o autorze, ilustratorce Elżbiecie Wasiuczyńskiej, ich metodach pracy, historii

6 Jak można zauważyć, chińskie tytuły w większości przypadków znacznie różnią się od polskich. Wywodzą się zazwyczaj od jednego z opowiadań zawartych $\mathrm{w}$ danym tomiku, ale tłumacz (wydawca?) często wybierał inną historię niż autor. Ponieważ nie dotarłam do materiałów, które zawierałyby owe tytuły zestawione w obu językach, dobrałam je w pary na podstawie zawartości spisów treści. 
i postaci Pana Kuleczki oraz recepcji opowiadań w Polsce. Trudno wywnioskować z tego tekstu, z jakim przyjęciem Pan Kuleczka spotkał się w Chinach, choć niewątpliwie wyczuwalne są ciepło i optymizm, a główny bohater nazwany został „idealnym rodzicem” (wanmei jiazhang). Można się domyślać, że - podobnie jak w przypadku książek Mizielińskich - wydawca sugeruje, iż opowiadania Widłaka powinny być czytane wspólnie, przez dzieci i rodziców, oraz dla jednych i drugich stanowić inspirację i przyczynek do przemyśleń.

Na temat twórczości Izabeli Mikrut (2016, Co się zdarzyło w piórniku; Wenju da kuangquan, przel. Zhong Lei) i Marcina Brykczyńskiego (2016, Chodzi o to, czy wiesz, co to. Zwierzęta; Dongwu da faxian, przeł. Qu Pengjie) w chińskich mediach pojawil się komentarz:

Są obcokrajowcami, ale miłość do dzieci nie zna granic. Wierzę, że te dwie książki są jak dwa magiczne nasiona, które przybyły z obcego kraju i w sercach chińskich dzieci wykiełkują najpiękniejszymi kwiatami. [Zhang 2016]

Dalej wymieniane są najistotniejsze cechy, jakie posiadać powinny obrazkowe książki dla dzieci, a których nie można odmówić wyżej wymienionym tytułom:

[...] korespondują z dziecięcym sposobem myślenia, uruchamiają u dzieci zainteresowanie czytaniem; mają wyrafinowaną kreskę i są bogate w istotne treści, co może wywierać na dzieci pozytywny wpływ; kształtują dziecięcą wyobraźnię i kreatywność. [Zhang 2016]

Spędziłam sporo czasu, poszukując informacji o innych pozycjach, które ukazały się na chińskim rynku, ale tu nie pomogło nawet wsparcie magicznych pomocników. Część linków do stron $\mathrm{z}$ artykułami jest już nieaktywna, inne kierują do witryn księgarni internetowych, na których znajdziemy tylko podstawowy opis książki, czasem recenzje, cytowane za innymi, zagranicznymi źródłami, co nie daje obrazu tego, jak radzą sobie nasi autorzy 


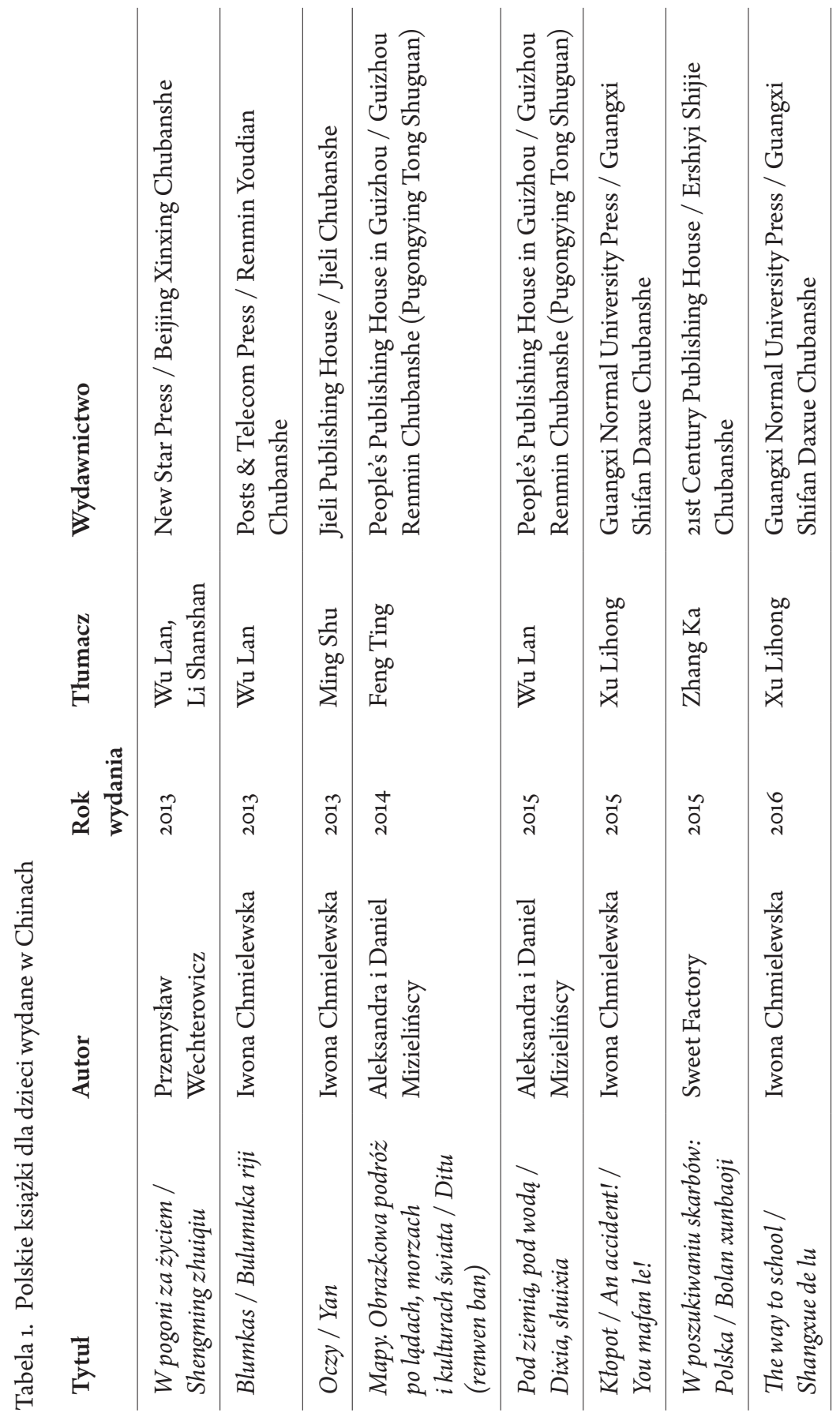




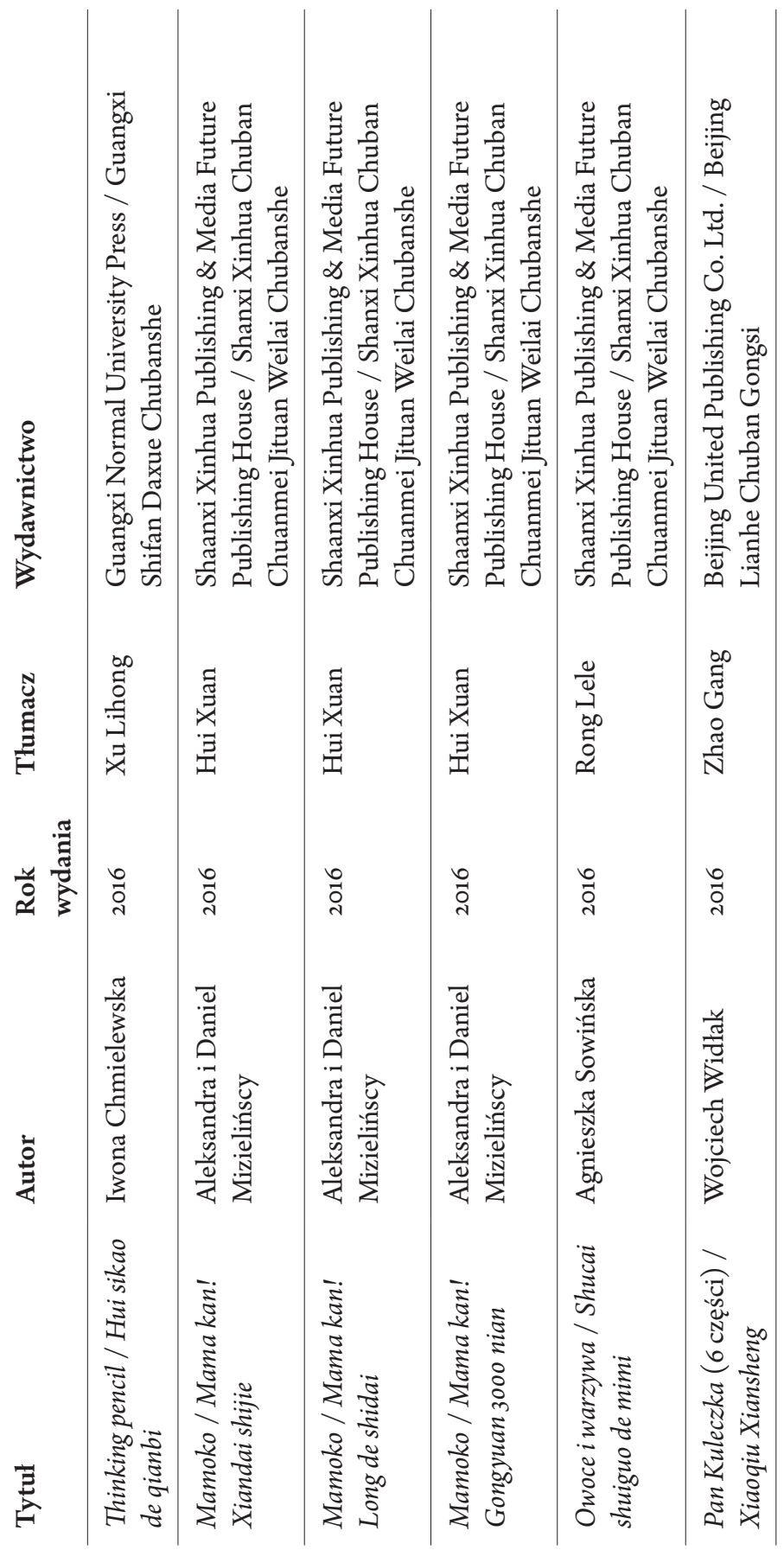




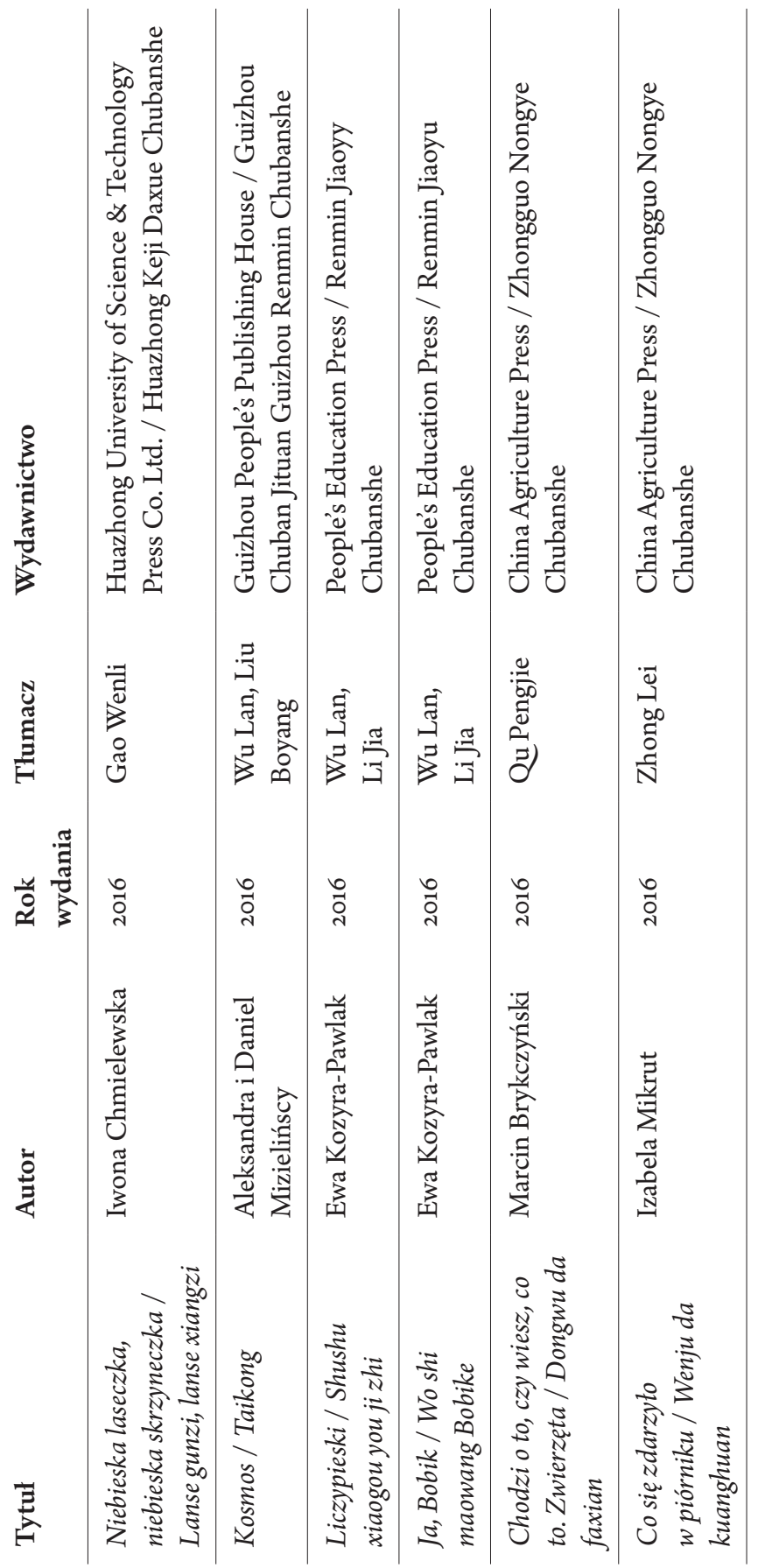


112 AGNIESZKA PATERSKA-KUBACKA

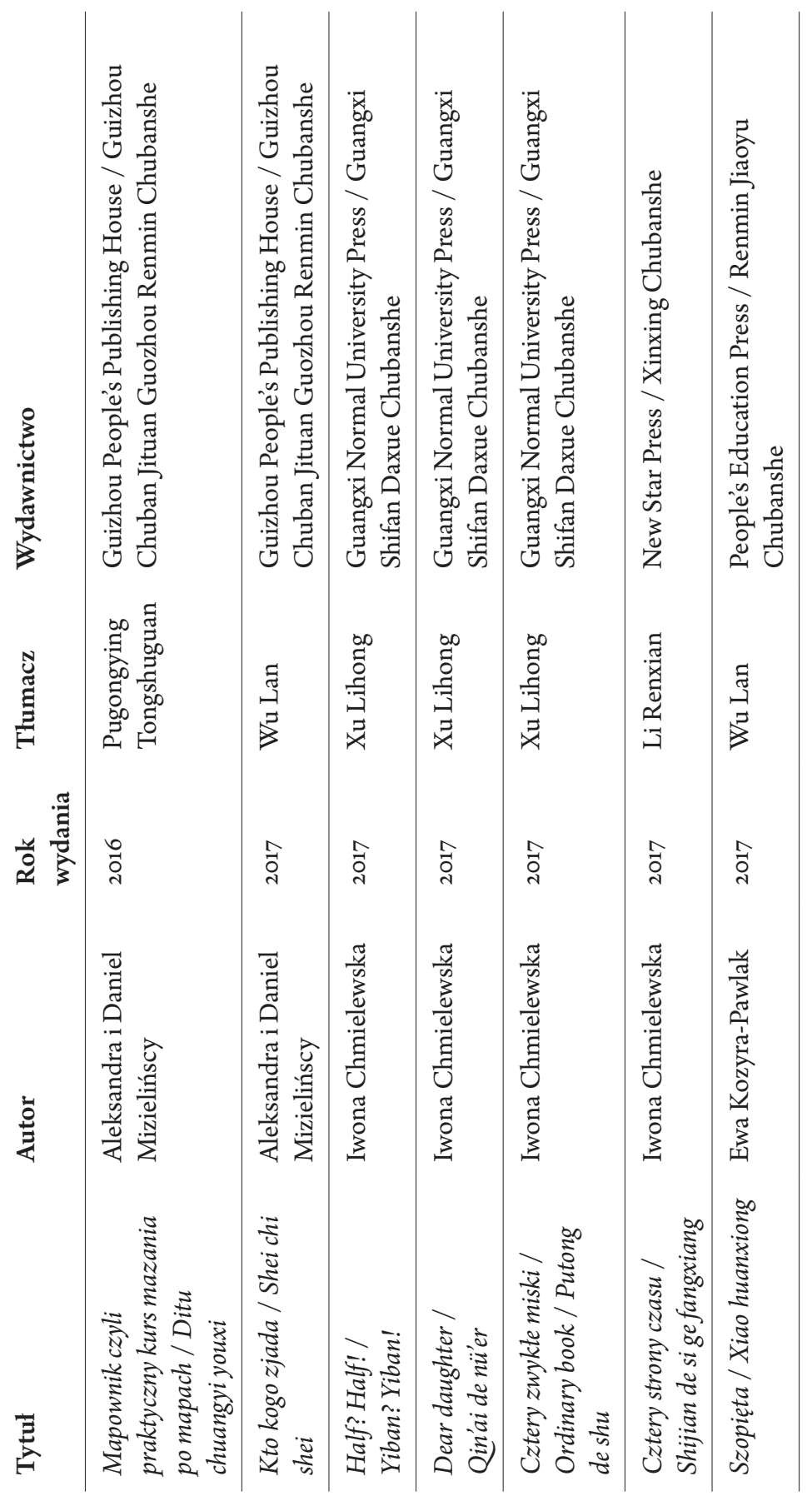




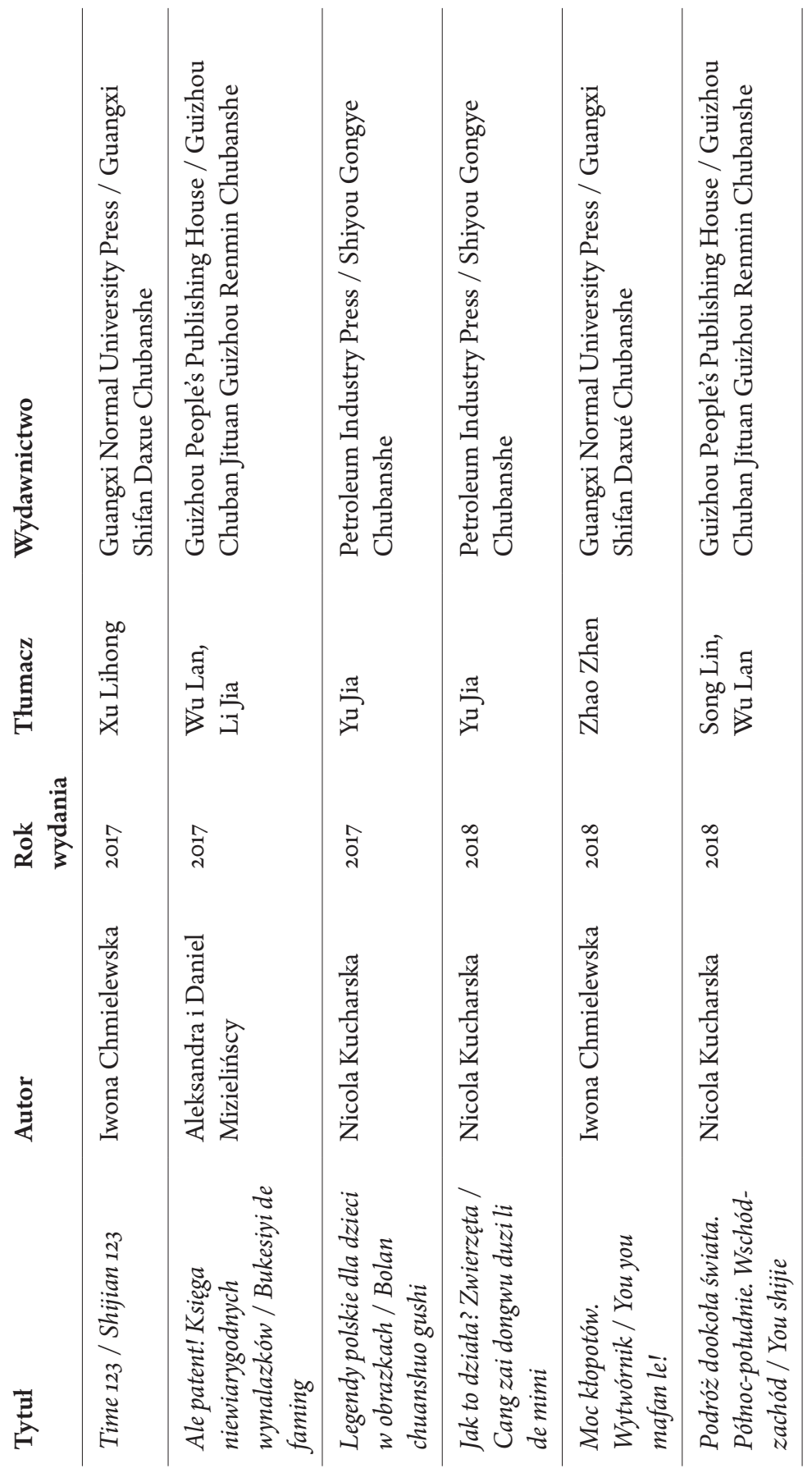


114 AGNIESZKA PATERSKA-KUBACKA

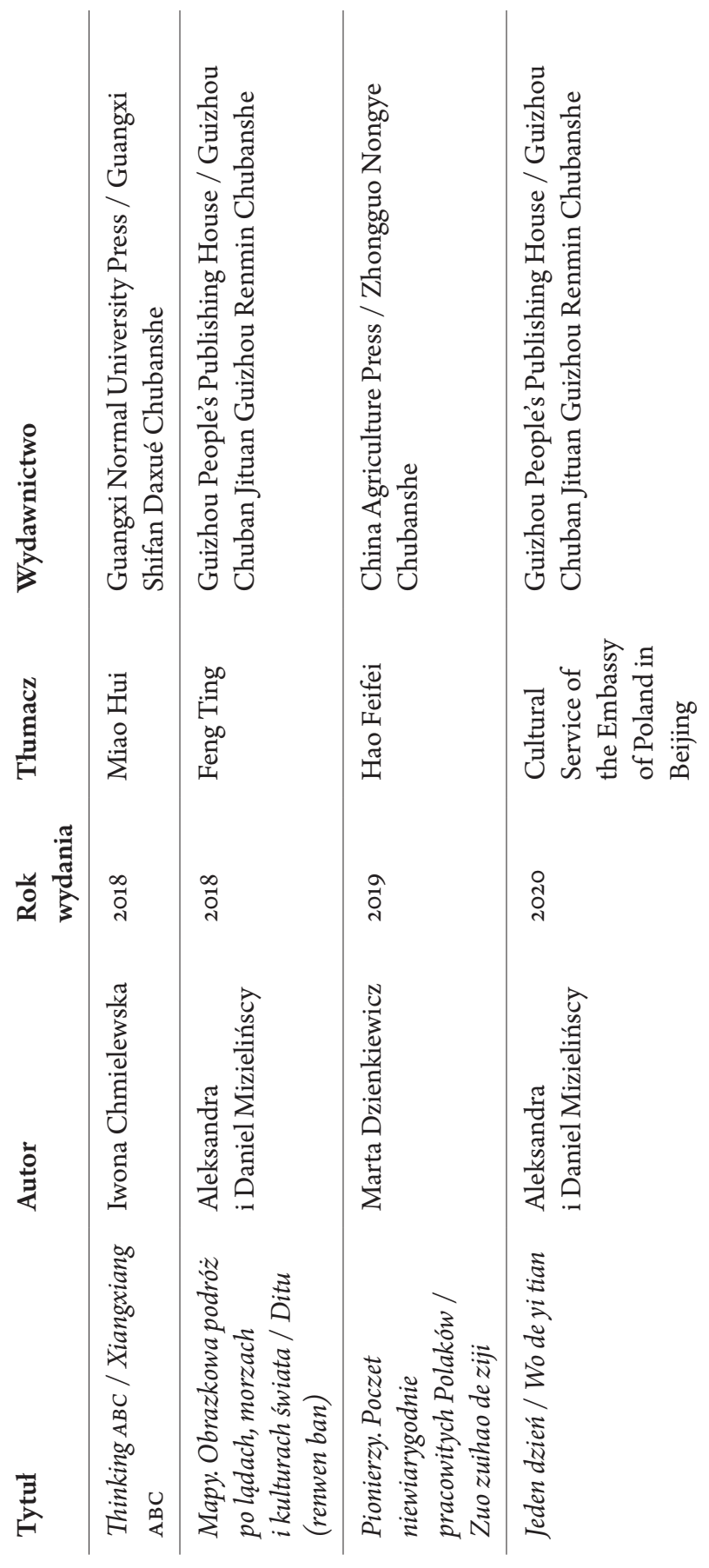

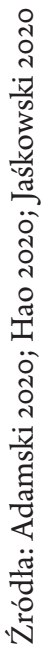


w Chinach. Na stronach 109-114 zamieszczam więc tylko tabelę, w której zebrałam nazwiska autorów i tytuły polskich książek dla dzieci wydanych w Chinach. Ich egzemplarze otrzymałam od pracowników Instytutu Polskiego oraz Instytutu Książki. W miarę możliwości uzupełniłam brakujące informacje danymi pochodzącymi z Internetu.

W 2018 roku oficyna PsyGarden Publishing Company (Xinling Gongfang) z Tajpej, przy wsparciu Instytutu Książki, który prowadzi Program Translatorski @ PolAnd, opublikowała przekład Króla Maciusia Pierwszego (Maidi guowang zhizhengji, przeł. Wei-Yun Lin-Górecka) [„Król Maciuś Pierwszy”... 2018]. Rok później w tym samym wydawnictwie ukazał się przekład książki Król Maciuś na bezludnej wyspie (Maidi guowang zai wuren dao, przeł Wei-Yun Lin-Górecka).

\section{Ile wyszło?}

Dotychczas nie udało mi się pozyskać danych o nakładach poszczególnych tytułów ani też informacji o liczbie sprzedanych egzemplarzy. Wspomniałam już jednak o nagłówkach internetowych artykułów, które sygnalizowały, że w Chinach kupiono „ponad milion książek” państwa Mizielińskich. Ich Mapy oraz D.E.S.I.G.N. miały dwa wydania, więc można się domyślać, że nakład wydania pierwszego został wyczerpany, a popyt wciąż istniał. Iwona Chmielewska opublikowała w Chinach trzynaście różnych tytułów (jeśli moje dane są aktualne). Wygląda więc na to, że cieszą się one dużą popularnością i generują zysk, skoro wydawane są wciąż kolejne pozycje (zważywszy na fakt, że obecnie dla wydawnictw bardziej liczą się finanse niż misja niesienia literatury „pod strzechy”).

Współpraca na polu tłumaczeniowo-wydawniczym to także jeden z punktów realizowanego od kilku lat przez rząd ChRL wieloaspektowego planu „16 + 1”, w którym uczestniczą kraje Europy Środkowo-Wschodniej, w tym Polska. W 2014 roku opracowano dokument, który postuluje „wspieranie Chin i krajów Europy Środkowo-Wschodniej w realizacji projektów współpracy w zakresie wzajemnego tłumaczenia i wydawania dzieł literackich” [Dakai 
Zhong-Dong... 2016]. De facto współpraca ta już się rozpoczęła i rozwijała się od dawna, ponieważ

od roku 2000 w Chinach wydano ponad 1300 książek autorów pochodzących z Europy Środkowo-Wschodniej, dotyczących literatury, ekonomii, polityki, historii etc. W Europie natomiast przetłumaczono i opublikowano w tym czasie dzieła takich pisarzy, jak Lu Xun, Mao Dun (1896-1981), Mo Yan (1955- ) czy Su Tong (1963- ). [Dakai Zhong-Dong... 2016]

Zhang Fan, redaktor pracujący w Poeple's Education Press (Renmin Jiaoyu Chubanshe), który był odpowiedzialny za przygotowanie dwóch książek Ewy Kozyry-Pawlak, o polskiej twórczości dla dzieci mówi tak: „W polskich książkach dla dzieci możemy dostrzec niezwykle wysoki poziom artyzmu. [...] Jestem pod wielkim wrażeniem profesjonalizmu polskich autorów i wydawców” [Dakai Zhong-Dong... 2016].

Wszystkie przytoczone fakty i przesłanki pozwalają z optymizmem spoglądać w przyszłość polskiej literatury dziecięcej w Chinach.

\section{Bibliografia}

Adamski Mateusz [m.adamski@instytutksiazki.pl] (2020), Polska literatura dziecięca w Chinach (PTCP Chiny 1999-2019), do: Agnieszka Paterska-Kubacka [agpater@amu.edu.pl], 24 kwietnia, [korespondencja osobista].

Beijing International Book... (2015), [dostęp: 12 maja 2020], https://tinyurl.com/ee574f85.

Dakai Zhong-Dong Ou 16 guo duoyuan wenhua wanhuatong

[Otwarcie wielokulturowego kalejdoskopu 16 krajów Europy Środkowej i Wschodniej] (2016), [dostęp: 14 maja 2020], https://www.sohu.com/a/111828718_268716.

Doktorzy Honorowi Uniwersytetu Gdańskiego (2020), [dostęp: 26 sierpnia 2020], https://tinyurl.com/vcs2zp7v.

Du le jiu hui aishang de shijie qi shu „Ditu (renwen ban)”, bu chumen rang haizi kan bian shijie! [Mapy - księga osobliwości świata, w której zakochasz się od pierwszego czytania, pozwoli dzieciom zobaczyć 
caly świat bez wychodzenia $z$ domu] (2018), [dostęp: 12 maja 2020], https://cutt.ly/QmDHFas.

Guo Zheng eliza 2016 (2020), мамоко Mama Kan! Xin shu fabu.

Wuzi huiben huo yinfa qinzi yuedu xin rechao [мамоко! Wychodzi nowy tom. Obrazkowe ksiązki bez znaków moga wywołać nowa fale wspólnego czytelnictwa wśród rodziców i dzieci], [dostęp: 14 maja 2020], https://tinyurl.com/2fuzebhv.

Hao Feifei [Anita; Feifei.Hao@msz.gov.pl] (2020), Polska literatura dziecięca $w$ Chinach (Polish Literature for kids published in Chinese), do: Agnieszka Paterska-Kubacka [agpater@amu.edu.pl], 28 kwietnia, [korespondencja osobista].

Instytut Polski Wydział Kultury... (2016), [dostęp: 26 sierpnia 2020], https://tinyurl.com/3v989n3y oraz https://tinyurl.com/yypwd3a6.

Jaśkowski Damian [Damian.Jaskowski@msz.gov.pl] (2020),

Polska literatura dziecięca w Chinach (Children-literature), [do:

Agnieszka Paterska-Kubacka (agpater@amu.edu.pl), 24 kwietnia, [korespondencja osobista].

Kaluta Izabella (2018), Instytut Książki na Beijing International Book Fair, [dostęp: 25 sierpnia 2020], https://tinyurl.com/cc7dd3vv.

Kaźmierczak Karol (2017), Milion ksiązek polskich autorów sprzedanych $w$ Chinach, [dostęp: 25 sierpnia 2020], https://tinyurl.com/3kfytemr.

Kong Xue, Zhao Zhen (2017), „Xiaoqiu Xiansheng” qidai shenmi hanxu de zhenli bei geng duo haizi gongxiang [Pan Kuleczka oczekuje, że coraz więcej dzieci będzie się wspólnie cieszyć ukryta, tajemniczą prawdą], „Xin Jingbao Dianzi Ban” [„The Beijing News”], [dostęp: 1 września 2020], https://tinyurl.com/m52x44c3.

„Król Maciuś Pierwszy”... (2018), [dostęp: 25 sierpnia 2020], https://tinyurl.com/p5getaf8.

Li Yinan (2017), Literatura polska w Chinach, Wydawnictwo Uniwersytetu Śląskiego, Gnome, Katowice.

Nuoya (2015), Shou hui quwei kepu huiben „Dixia, shuixia” shoufa, kaiqi jiju xianchanggan de faxian tansuo zhi lü [Pierwsze wydanie ręcznie malowanej, zachwycajacej, popularno-naukowej ksiązki obrazkowej "Pod ziemia, pod woda" rozpoczęto odkrywcza, badawcza podróż dajacca poczucie „bycia na miejscu zdarzeń”], [dostęp: 12 maja 2020], https://tinyurl.com/kspkgrk.

Poloniści z Szanghaju... (2017), [dostęp: 3 września 2020], https://tinyurl.com/3etxeuft.

Polska na targach... (2012), [dostęp: 12 maja 2020], https://tinyurl.com/3f6tuh2p. 
Polskie książki $w$ Chinach (2016)7, [dostęp: 25 sierpnia 2020], https://tinyurl.com/6zmrb8bc.

Prokop Daria (2016), Język polski i kultura polska w Chinach, Instytut

Filologii Polskiej Uniwersytetu Wrocławskiego, [dostęp: 3 września 2020], https://tinyurl.com/5486nyc4, [nieopublikowana praca magisterska].

Sajewicz Tomasz (2017), Polacy sprzedali ponad milion książek w Chinach, [dostęp: 25 sierpnia 2020], https://tinyurl.com/v6rymp6t.

Widłak Wojciech [wojwid@o2.pl] (2020a), Literatura dziecięca $w$ Chinach, do: Agnieszka Paterska-Kubacka [agpater@amu.edu.pl], 22 kwietnia, [korespondencja osobista].

Widłak Wojciech [wojwid@o2.pl] (2020b), Literatura dziecięca $w$ Chinach, do: Agnieszka Paterska-Kubacka [agpater@amu.edu.pl], 23 kwietnia, [korespondencja osobista].

Zhang Ling'er (2016), Tongxin wuguojie [Dziecięce serce bez granic], [dostęp: 14 maja 2020], https://tinyurl.com/mx2kwypc.

Zhao Gang (2010), Profesor Yi Lijun, „Postscriptum Polonistyczne”, z. 2 (6), s. 25-30.

Agnieszka Paterska-Kubacka

\section{Polish Children's Literature in China}

Polish literature has been present in China since 1906. The first Polish literary text translated into Chinese was Latarnik (The Lighthouse Keeper) by Henryk Sienkiewicz. Contemporary fans of Polish novella and novel were reading indirect translations since the Chinese novelists, who did not speak Polish, usually based their translations on the Japanese versions. In my years of contact with Chinese culture and literature, I have never come across any mention of translations of Polish or Eastern European children's literature. Once I started my research into this subject, I quickly learned what caused the lack of information on it. It turned out that it was quite difficult to find any credible information on what has been translated, in what volume it was published and what the reactions of young readers were.

As a result, this article is merely an introduction to the research on Polish children's literature in People's Republic of China and focuses almost exclusively on latest publications, i.e. released in the twenty-first century. To a significant extent, it is based on data collected from people actively

7 Taką datę podano na stronie internetowej, tuż pod nagłówkiem. Dlaczego dzień przed rozpoczęciem targów pisano, że „Polska była gościem”, „książki zostały pokazane" etc.? 
participating in promoting Polish culture in China via email. I received a lot of valuable data from Wojciech Widłak - one of the authors whose children's books were published in China. The article is practically a short catalogue of books published on the Chinese market, but it also presents the few reviews I have managed to find in Chinese sources. There is also a presentation of the translators and it is worth noting that Polish children's literature has been taken care of by the best among those studying Polish literature in China. I hope that this article will be the first of many on the position, popularity and reception of Polish children's literature in China.

Keywords: Polish fiction; children's literature; fairy tale; translations of Polish literature; Polish literature in China.

Agnieszka Paterska-Kubacka - poznanianka, sinolożka, doktor literaturoznawstwa (chińska proza klasyczna). Od 2016 roku adiunkt na Uniwersytecie im. Adama Mickiewicza w Poznaniu, naucza przede wszystkim przedmiotów związanych z literaturą i kulturą chińską. W kręgu jej literackich zainteresowań badawczych znajdują się: bajki, baśnie, stworzenia i zjawiska nadprzyrodzone, mitologia, systemy filozoficzno-religijne, wierzenia pozagrobowe. 
